\title{
Preservation of thin tephra
}

\author{
Russell Blong $^{1 *}$ (D) Neal Enright ${ }^{2}$ and Paul Grasso ${ }^{3}$
}

\begin{abstract}
The preservation of thin (<300 mm thick) tephra falls was investigated at four sites in Papua New Guinea (PNG), Alaska and Washington, USA. Measurements of the variations in the thickness of: (i) Tibito Tephra $150 \mathrm{~km}$ downwind from the source, Long Island (PNG) erupted mid-seventeenth century; (ii) St Helens W tephra (erupted 1479-80 A.D.) on the slopes of the adjacent Mt. Rainier in Washington State; (iii) Novarupta (1912) tephra preserved on Kodiak Island (Alaska, USA); and (iv) an experimentally placed tephra at a site near Mt. Hagen (PNG) allow tentative conclusions to be drawn about the relative importance to tephra preservation of slope gradients, vegetation cover and soil faunal activity. Results for the experimental tephra suggest that compaction occurs rapidly post-deposition and that estimates of tephra thickness and bulk density need to indicate how long after deposition thickness measurements were made.

These studies show that erosional reworking of thin tephra is not rapid even on steeper slopes in high rainfall environments. In Papua New Guinea a 350-year old tephra is rarely present under forest but is well-preserved under alpine grasslands. On Mt. Rainier 500-year old tephra is readily preserved under forest but absent under grasslands as a result of gopher activity. Despite the poor relationship between tephra thickness and slope steepness the thickness of thin tephras is highly variable. On Kodiak Island thickness variability across a few metres is similar to that observed across the whole northeast of the island. The measured variability reported here indicates large sample sizes are necessary to adequately estimate the mean thickness of these thin tephra.

These results have implications for the preparation of isopach maps, estimation of tephra volumes and elaboration of the potential consequences of tephra falls.
\end{abstract}

Keywords: Tephra fall, Preservation, Compaction, Thickness, Erosion, Vegetation, Fauna, Sample size

\section{Introduction}

Tephra thickness is influenced by eruption dynamics, topographic variations, compaction, erosion and deposition, and bioturbation (Engwell et al. 2013). While the relative importance of these influences is rarely examined numerous observations attest to the rapid erosion from hillslopes of recently emplaced tephra. Deep rills and gullies are quickly cut in fresh tephra producing some of the highest recorded erosion rates (Cilento 1937, p47-8; Huggins 1902, p20; Waldron 1967, p11; Ollier and Brown 1971; Higashi et al. 1978; Kadomura et al. 1978; Lowdermilk and Bailey 1946, p286; Collins et al. 1983).

As much as one third to one half of the tephra may be removed from the slopes within one year or less of emplacement (Anderson and Flett 1903, p453; Waldron

\footnotetext{
* Correspondence: rblong43@gmail.com

${ }^{1}$ Risk Frontiers, Macquarie University, Sydney, NSW 2009, Australia Full list of author information is available at the end of the article
}

1967, p11), though more detailed studies at Mount St Helens after the 1980 eruption suggest only $11 \%$ of tephra was removed in the first year (Collins et al. 1983) and that erosion rates declined dramatically with time (Collins and Dunne 1986). The amount of vegetation remaining on tephra-mantled slopes also influences erosion rates (Collins et al. 1983).

Observations supporting the rapid erosion of tephra have generally been made close to the source volcanoes where the tephra was at least $300 \mathrm{~mm}$ thick, and sometimes considerably thicker. Erosional reworking and/or survival of thin deposits (i.e., $10-300 \mathrm{~mm}$ ) have not been reported in any detail. Although emplacement of thin tephra is usually less destructive of the vegetation cover it is not clear whether erosion of thin tephra is similarly rapid, or whether preservation is more or less likely.

Most studies of thin tephra relate to their use as chronostratigraphic marker beds and are commonly based on tephra preserved in lakes and/or swamp 
deposits. By and large, preservation of thin tephra in terrestrial environments is poorly documented despite the fact that terrestrial areas experiencing relatively thin tephra falls are generally substantially larger than those receiving thicker deposits (e.g., Payne and Symeonakis 2012). Nonetheless, thin tephra are of considerable value in geomorphic, pedologic, geologic and archaeologic investigations as they can form obvious marker horizons and may cover tens of thousands of square kilometres (e.g. Lowe 2011; Arnalds 2013).

The present contribution sets out observations on the preservation of thin tephra at four sites: near Mt. Hagen and in the Western Finisterre Ranges, Papua New Guinea, on the slopes of Mt. Rainier, Washington, USA, and on Kodiak Island, Alaska, USA. In each study, our aims were to determine the variability in thin tephra preservation and to elucidate, so far as possible, the factors that encourage or prevent preservation by recording multiple observations in quite limited areas. While each of these studies was limited in duration they span a variety of geomorphic environments and ecosystems and include one experimental study (at Mt. Hagen), two studies of thin tephra emplaced 350-500 years ago but not recorded in written accounts until the second half of the twentieth century (in the Western Finisterre Ranges, PNG and on the slopes of Mt. Rainier, USA), and one well-documented historic eruption (Kodiak Island, USA).

\section{The study areas}

\section{Mt. Hagen}

In 1977 seven small experimental plots were established near Mt. Hagen town $\left(5.8^{\circ} \mathrm{S}, 144.25^{\circ} \mathrm{E}\right)$ in the Western Highlands Province of Papua New Guinea (Fig. 1) at an elevation of $1500 \mathrm{~m}$. The plots measured $0.12 \mathrm{~m}^{2}$ and were placed on surfaces with slopes of less than three degrees. Plot surface covers included long $(200-350 \mathrm{~mm})$ and short (20-40 $\mathrm{mm}$ ) grasses providing $100 \%$ ground cover and bare ground. The tephra used for the experiment was formed by crushing a lightly-consolidated 14,000 year old tephra to pass a $2 \mathrm{~mm}$ sieve, with approximately half the material finer than $1 \mathrm{~mm}$. This tephra was broadcast by hand from a height of $500 \mathrm{~mm}$ to form layers $10-60 \mathrm{~mm}$ thick.

\section{Western Finisterre ranges}

The Western Finisterre Ranges lie in Morobe Province, Papua New Guinea at $6^{\circ} \mathrm{S}, 146.5^{\circ} \mathrm{E}$ (Fig. 1). In 1979 a study was made of the erosion and preservation of Tibito Tephra, erupted from Long Island (VEI 6) probably around 1660 A.D., in an area of the Finisterre Ranges at an elevation of $\sim 3600 \mathrm{~m}$. In this area, approximately $95 \mathrm{~km}$ from Long Island, Tibito Tephra is an olive-green fine-medium sand about $50 \mathrm{~mm}$ thick (Blong 1982). Annual rainfall at high altitude in the Western Finisterre Ranges is unknown but evidence elsewhere in

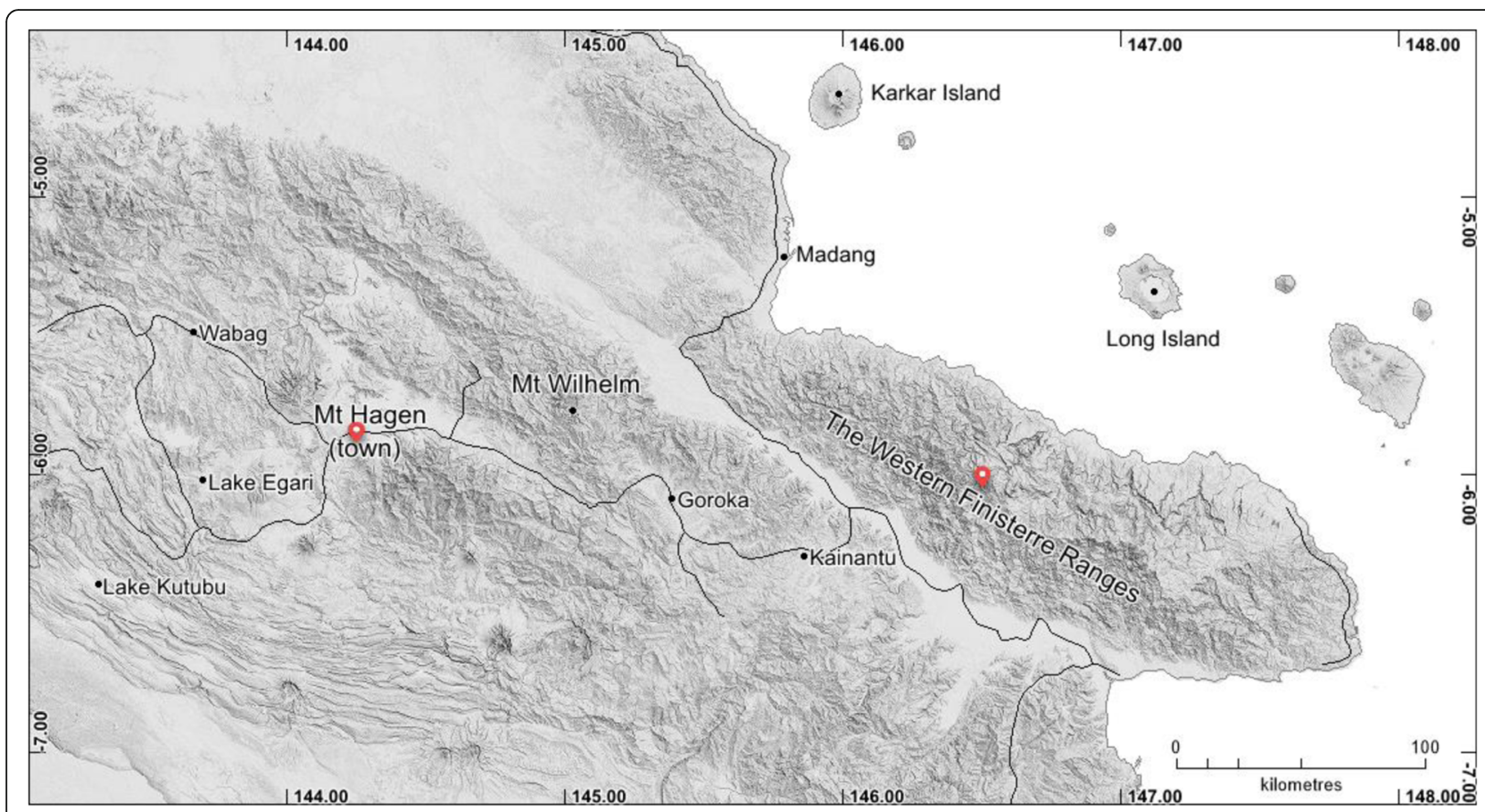

Fig. 1 Part of the Papua New Guinea mainland showing the town of Mt. Hagen where the compaction experiment was conducted and the location of the field sample of Tibito Tephra in the Western Finisterre ranges 
Papua New Guinea suggests it is likely to be at least 3000-4000 mm.

In the Western Finisterres 14 sites were selected with up to 14 samples made at each site within a 3 m radius, but with no sample within $40 \mathrm{~cm}$ of another. All sites were selected within an area of a few hectares in alpine grassland. Soil cores were taken manually using a $30 \mathrm{~mm}$ diameter corer pushed into the ground to the hilt. All cores were taken in moss covered gaps between grass and bromeliad clumps averaging $30 \mathrm{~cm}$ height.

Each of the 14 sites was assigned to a geomorphic environment (see Table 3 ) and broadly grouped as low slope angle crest, steep erosional slope, or low slope angle valley floor. Percent cover for each plant species was estimated visually for $10 \times 1 \mathrm{~m}^{2}$ subunits of a single $10 \mathrm{~m}^{2}$ quadrat at each site, and the mean value used as the best estimate. Cover data were analysed using a sum of squares agglomerative (SSA) classification (Orloći 1978) which provides a classification of both sites and species. Pollen assemblages immediately above and below Tibito Tephra were analysed for two sediment cores to determine both the nature of the vegetation at the time of the tephra deposition and whether vegetational change occurred after tephra emplacement.

\section{Mt. Rainier}

Sites in the southern and eastern part of Mt. Rainier National Park, Washington, USA were selected for a study of the preservation of Mount St Helens W tephra (Fig. 2). In this area, Mount St Helens W tephra is a 10$80 \mathrm{~mm}$ thick, white to light brown layer of loose sandsized pumiceous and crystal-rich ash. In some exposures dark minerals and lithic fragments are common, giving the tephra a "salt and pepper" appearance (Mullineaux 1974, p37-38). St Helens W, dated to 1479-1480 A.D. on the basis of tree ring counts (Yamaguchi 1983), is one of the youngest tephra in this area of Mt. Rainier National Park to form a conspicuous bed. Layer W in Mt. Rainier National Park is the St Helens Wn tephra of Mullineaux et al. (1975, p334). Observations reported here were made in alpine meadows at Sunrise Ridge and Chinook Pass and in forest at Ohanopecosh. Figure 2 shows the distribution of the tephra in the park area (after Mullineaux 1974).

\section{Kodiak Island}

Twenty six sites on north eastern Kodiak Island, Alaska (Fig. 3) were investigated in 1978 to determine the influence of slope angle on erosion and preservation of

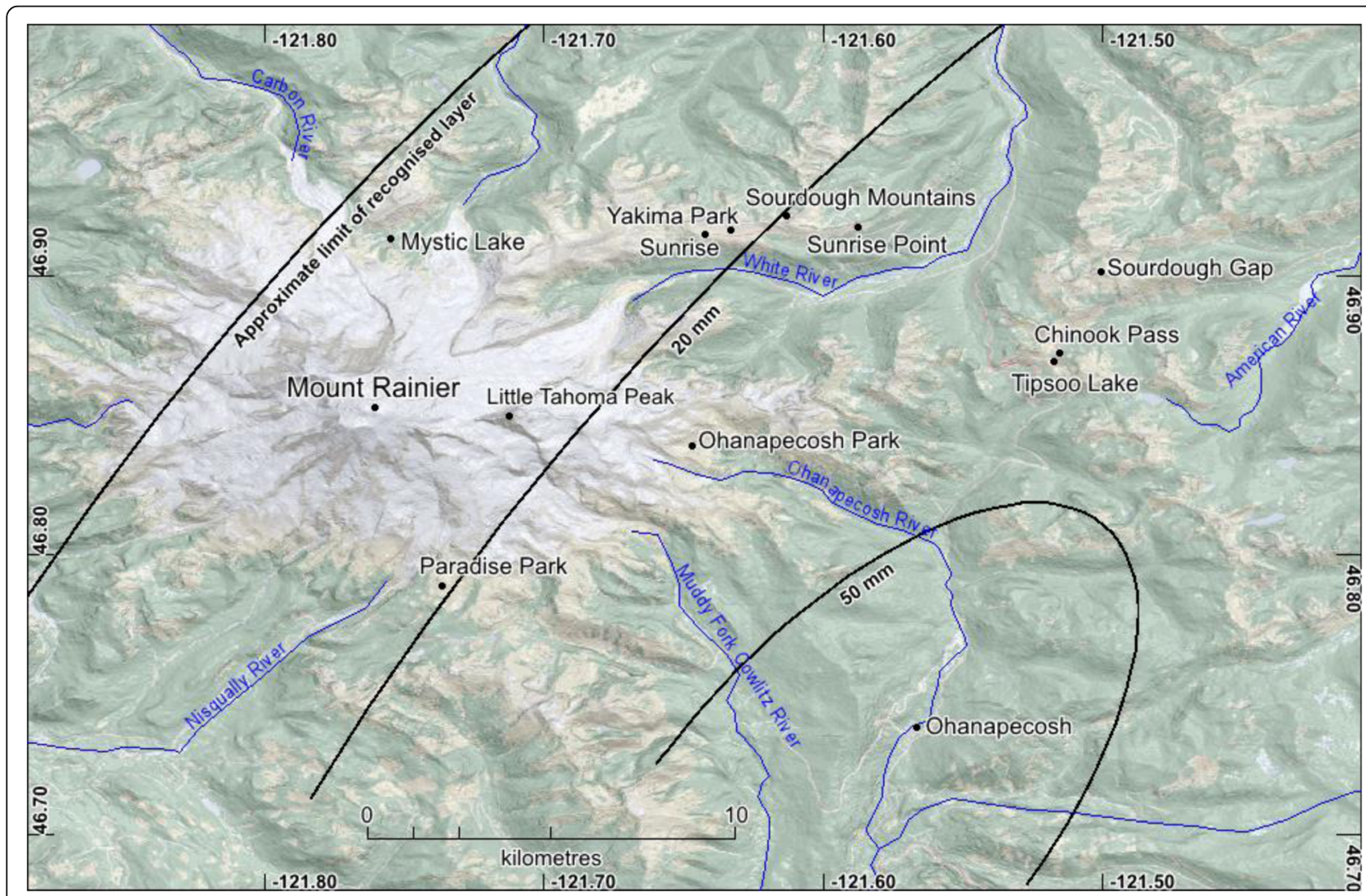

Fig. 2 Distribution of St Helens W tephra in Mt. Rainier National Park area, Washington, USA. (tephra thickness after Mullineaux 1974, p39). The observations referred to in this paper were made near Sunrise, at Chinook Pass and in forest at Ohanopecosh 


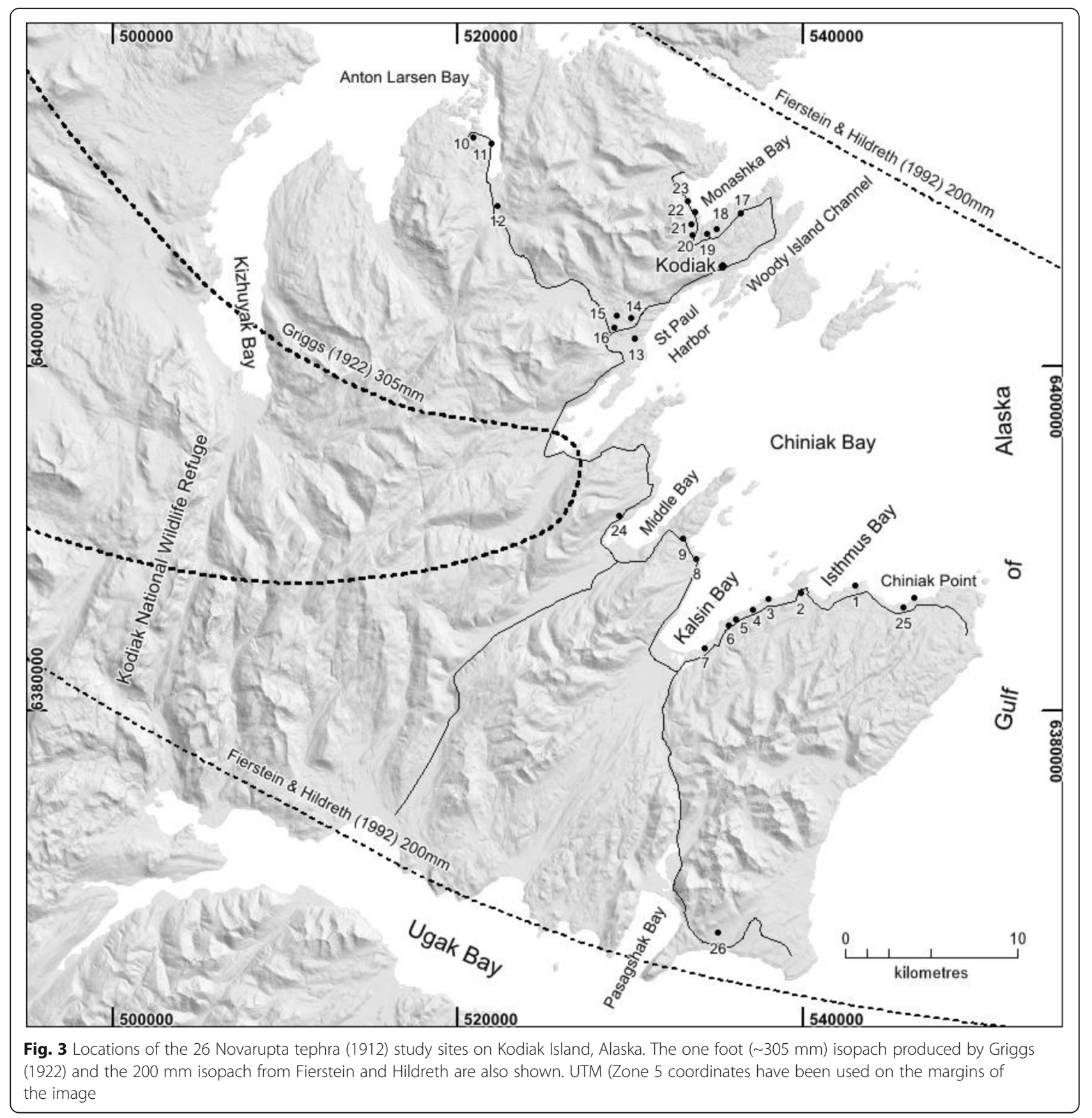

Novarupta (1912) tephra, the product of the world's most voluminous eruption in the twentieth century (Hildreth and Fierstein 2000). Kodiak town is about $170 \mathrm{~km}$ SSE of Novarupta. Tephra fell to a thickness of about $450 \mathrm{~mm}$ on Kodiak town, $170 \mathrm{~km}$ downwind from the vent, over a period of about $60 \mathrm{~h}$, but rapidly compacted to about $250-300 \mathrm{~mm}$ (see below). Our field observations were made before the detailed analysis of Fierstein and Hildreth (1992). While comparison of locations on our Fig. 3 and Fierstein and Hildreth's Fig. 2 suggests we probably examined some of the same field sites, the stratigraphic sequence we followed was the earlier 3layer division described by Reiger and Wunderlich (1956) (see Fig. 4):

Layer 3 - firm, compact, dacitic, light grey silt loam, 25-50 mm (deposited overnight in Kodiak 8-9 June, 1912).

Layer 2 - yellow-brown dacitic coarse silt loam, 75$125 \mathrm{~mm}$ (deposited from noon on the 7th to $1430 \mathrm{~h}$ on the 8th June).

Layer 1 - loose, predominantly rhyolitic light yellowbrown loamy fine sand, $25-50 \mathrm{~mm}$ grading to grey- 


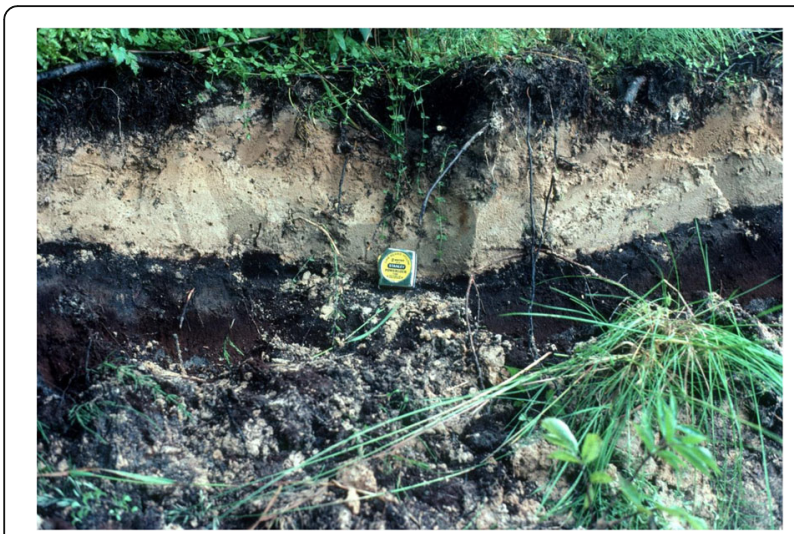

Fig. 4 An exposure of Novarupta (1912) tephra on the eastern side of Kodiak Island. The sharp base of Layer 1 is clearly visible with a diffuse boundary to the overlying yellow-brown Layer 2. The lightgrey silt loam of Layer 3 is only visible in some of the exposure

brown loose fine sand, 75-100 $\mathrm{mm}$ (deposited from $5 \mathrm{pm}$ on 6 th June to 7 am on 7 th June). ${ }^{1}$

As the layering of the tephra is still readily observed it is possible to determine whether the tephra is still in situ at specific sites, erosionally reworked, or absent (Fig. 4). In the field, a distinction was made between "essentially in situ" tephra and "reworked" tephra. The former is generally characterised by the presence of Layer 1 and Layer 2 and the possible absence of Layer 3. Griggs' (1918), p41 statement that Layer 3 "has almost everywhere blown away, leaving the present surface of the ash composed usually of the middle brown layer", would seem to be only partly true.

Most of the 26 sites examined were covered with low shrubs, grasses, ferns, fireweed (Epilobium sp.) and/or salmonberry; only a few sites were under spruce or alder. Most sites were on planar hillslopes, nearly all sites were underlain by $500 \mathrm{~mm}$ or more of till on either Cretaceous metamorphic rocks or a variety of Quaternary sediments. Some of the surface processes operating in the Kodiak - Katmai environment have been described by Hilton (2003).

\section{Factors influencing erosion and preservation of thin tephra \\ Compaction}

The bulk density of freshly-fallen tephra is low but is also highly variable (Table 1 ). Published values range from 0.23 to $1.23 \mathrm{~g} \mathrm{~cm}^{-3}$ with a mean value of about $0.69 \mathrm{~g} \mathrm{~cm}^{-3}$, though the time between emplacement and measurement is rarely known. On the other hand, values for compacted tephra range from about 1.3 to $1.8 \mathrm{~g} \mathrm{~cm}^{-3}$ (Moore 1967, p19; Waldron 1967, p5; Duncan and Vucetich 1970).

The changes in density implied by these values also imply a change in thickness: for example, Aramaki (1956, p200) reported changes in thickness at a site $13 \mathrm{~km}$ southwest of Asama crater; immediately after the 1783 eruption the alternating layers of pumice and fine ash were reported as $1200 \mathrm{~mm}$ thick, with compaction within a few months to $1050 \mathrm{~mm}$. One hundred and seventy years later the layer was recorded as only c. $650 \mathrm{~mm}$ thick. The decrease in thickness was attributed to compaction and not to erosion. While Collins et al. (1983) reported no discernible systematic change in the bulk density of Mount St Helens (1980) tephra over a period of 12 months, their measurements did not begin until 4 months after the eruption.

Accounts describing the thickness of the tephra deposited at Kodiak on 6-9 June 1912 illustrate the difficulties in sorting out the influences of compaction, erosion and redeposition. Nellie Erskine, wife of one of Kodiak's prominent businessmen, in writing to her mother a few days after the event, described the tephra as about $2 \mathrm{ft}$ $(600 \mathrm{~mm})$ thick. On 20 June she wrote to her mother again commenting that the tephra was "on the level 14

Table 1 Bulk densities of freshly-fallen tephra as reported in a range of previous studies

\begin{tabular}{llll}
\hline Thickness of tephra & Bulk density $\mathrm{g} / \mathrm{cm}^{3}$ & Eruption and year & Reference \\
\hline $38 \mathrm{~mm}$ & 0.23 & Soufrière St Vincent, 1902 & Anderson and Flett 1903, p475 \\
$25-300 \mathrm{~mm}$ & 0.25 & Soufrière St Vincent, 1902 & Anderson and Flett 1903, p475 \\
$9.5-13 \mathrm{~mm}$ & $0.35-0.47$ & Soufrière St Vincent, 1902 & HMSO 1903, p33 \\
$30 \mathrm{~mm}$ & 0.93 & Shiveluch, 1964 & Gorshkov and Dubik 1970, p268 \\
$2.5 \mathrm{~mm}$ & 0.80 & Shiveluch, 1964 & Gorshkov and Dubik 1970, p269 \\
$20 \mathrm{~mm}$ & 1.23 & Bezymianny, 1955 & Gorshkov 1959, p86 \\
$20 \mathrm{~mm}$ & 1.12 & Bezymianny, 1955 & Gorshkov 1959, p87 \\
$6 \mathrm{~mm}$ & 0.58 & Bezymianny, 1955 & Gorshkov 1959, p80 \\
$16.6 \mathrm{~mm}$ & 0.66 & Bezymianny, 1955 & Gorshkov 1959, p81 \\
$25 \mathrm{~mm}$ & 0.64 & Bezymianny, 1955 & Gorshkov 1959 \\
$5 \mathrm{~mm}$ & $0.6-0.8$ & Hekla, 1970 & Thorarinsson and Sigvaldason 1972, p273 \\
& $0.7-0.92$ & & \\
\hline
\end{tabular}


inches $[350 \mathrm{~mm}]$ and in places as high as your head where it is piled up" (Erskine 1962, p140, p192). Captain K W Perry's account published in the Washington Sunday Sun on 2 March 1913, but taken from his earlier official report as the senior government official in Kodiak at the time of the eruption, gives the tephra thickness as 22 in. (550 mm). Martin (1913, p172) states the thickness as 10 in. $(250 \mathrm{~mm})$ in September 1912. Griggs $(1918$, p3) reports that Kodiak was "covered about a foot deep" (300 mm) and H Erskine (1940) gives the thickness at 18 in. (450 mm). Wilcox (1959, p416) gives the thickness at Kodiak village as about 10 in. $(250 \mathrm{~mm})$. The cumulative ash fall map of Fierstein and Hildreth (1992) shows thicknesses of 200-300 mm in the Kodiak town area on the north eastern part of Kodiak Island. Observations made by the first author 66 years after the tephra fall (i.e. in 1978) indicate that the tephra has compacted to an average thickness of $150-210 \mathrm{~mm}$ on those sites where all three layers are present (that is, in the absence of significant erosion or redeposition).

All these observations (both measured and estimated thicknesses) could be substantially correct but made at different times after the eruption and, perhaps, in different parts of Kodiak town. Similarly, the wide range of reported bulk densities of fresh tephra in Table 1 may be partly a function of varying intervals between emplacement and observation.

Experimental plots set up in Mt. Hagen provide additional data on the compaction of tephra. Table 2 sets out the tephra thicknesses and plot conditions at the beginning of the experiment. For most of the more than 2 years measurements were made, however, the plots were covered in long grass.

Data from the Mt. Hagen experiment indicate compaction of tephra on the plots over a two-year period (Table 2), however, the most dramatic decrease in thickness for some plots occurred in the first few days. These initial measurements were based on the elevation of markers above the tephra surface while subsequent measurements were determined by digging up portions of the plot. Thicknesses became more variable with time, with some of this variability contributed by upward mixing by soil fauna which increased the apparent thickness of the layer (Table 2). By the end of the experiment the tephra on most plots was covered by up to $5 \mathrm{~mm}$ of organic rich topsoil indicating active bioturbation by soil organisms (cf. Wood and Johnson 1978), but the layer had not been destroyed by this mixing and new surface layer development.

The experimental tephra deposition plots were established at Mt. Hagen in January, a month with c.250$300 \mathrm{~mm}$ rainfall. Two days after plot establishment tephra which had bent blades of grass had been reworked downwards, but on plots with grass 200$350 \mathrm{~mm}$ tall many grains had still not reached the ground surface. Within a week it became clear that raindrop impact was important in compacting the experimental tephra. There was little evidence that tephra was splashed from the plot (the energy of falling rain drops being absorbed by the low-density tephra), but tephra thickness had been reduced by $10 \mathrm{~mm}$ or more on three plots (Fig. 5). On plot 2 some areas protected by leaves were still at the original elevation while most of the plot surface had compacted. There was no evidence of surface crusting.

After 16 days puddled surfaces appeared on some plots, minor flow lobes had occurred from the margins of the 50-55 mm thick tephra plots and there was evidence of tephra splashed upwards to heights of 150 $180 \mathrm{~mm}$ on the corner marker pegs. On plots with tall grass some tephra was still as much as $100 \mathrm{~mm}$ above the ground surface; that is, the tephra had still not reached the ground. On these plots there was a tendency for the tephra to form lenses rather than a continuous cover. Tephra thicknesses were not recorded on these plots as undue surface disturbance would have resulted.

The observations made on these experimental plots indicate that much of the decrease in thickness results from compaction and that much of the compaction of thin tephra occurs in the first few weeks after deposition, particularly during the rainy season. Clearly, this change in thickness, essentially in the absence of erosion, implies dramatic changes in bulk density of fresh tephra. The results suggest that the apparent ranges of values of

Table 2 Site conditions and tephra thicknesses at the Mt. Hagen, PNG experimental plots

\begin{tabular}{|c|c|c|c|c|c|c|c|c|}
\hline \multirow{2}{*}{$\begin{array}{l}\text { Plot } \\
\text { No }\end{array}$} & \multirow[t]{2}{*}{ Vegetation } & \multirow{2}{*}{$\begin{array}{l}\text { Slope } \\
\text { angle (degrees) }\end{array}$} & \multirow{2}{*}{$\begin{array}{l}\text { Initial } \\
\text { thickness (mm) }\end{array}$} & \multicolumn{5}{|c|}{ Subsequent thickness (mm) } \\
\hline & & & & 7 days & 16 days & 30 days & 236 days & 767 days \\
\hline 1 & Grasses $20-40 \mathrm{~mm} ;<5 \%$ bare ground; dense root mat & 5 & 50 & 35 & 25 & $\sim 20$ & 25 & $20-30$ \\
\hline 2 & Grasses $20-40 \mathrm{~mm} ; 40-50 \%$ bare ground & 0.5 & 50 & 35 & $25-30$ & $20-25$ & $20-30$ & $25-30$ \\
\hline 3 & Grasses $<20 \mathrm{~mm} ; 40-50 \%$ bare ground & 2 & 30 & 29 & $\sim 15$ & 10 & $10-12$ & $15-20$ \\
\hline 4 & Dense tall grasses 200-350 mm; no bare ground & 1 & $20-30$ & - & - & - & 20 & $<20$ \\
\hline 5 & Dense tall grasses 200-3000 mm; no bare ground & 1 & $50-60$ & - & - & - & 40 & $25-30$ \\
\hline 6 & Grasses $20-40 \mathrm{~mm} ;<5 \%$ bare ground & 7 & 10 & - & - & - & $5-10$ & $<5$ \\
\hline 7 & Bare soil dug over to spade depth & 3.5 & 25 & - & $>10$ & - & $\sim 10$ & $\sim 20$ \\
\hline
\end{tabular}




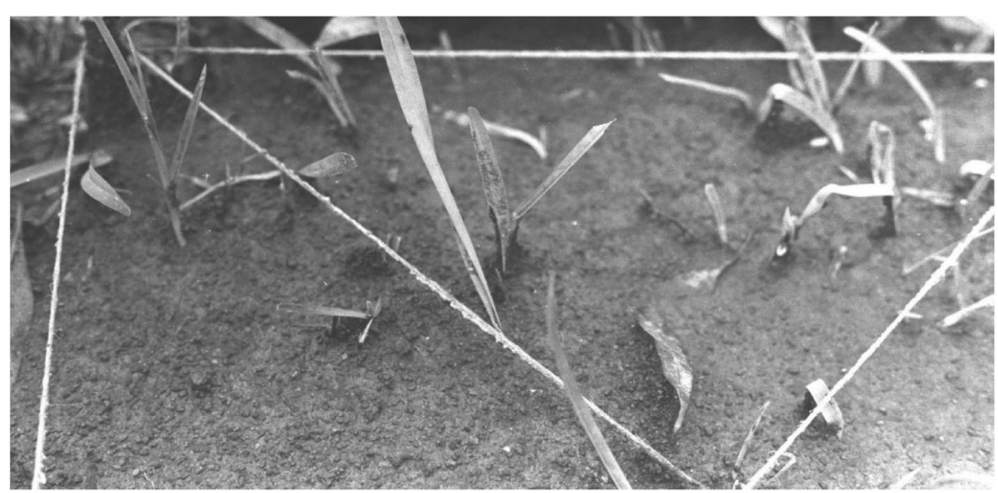

Fig. 5 Part of Plot 216 days after the start of the experiment. Compaction by raindrop impact is evident as the taut strings, initially flush with the tephra surface, stand proud. Numerous grass shoots have penetrated the tephra surface. The initial thickness of $50 \mathrm{~mm}$ has been reduced to $25-$ $30 \mathrm{~mm}$ in just 16 days

bulk density recorded in Table 1 should be interpreted with caution. Similarly, care must be taken that the rapid thinning of deposits by compaction is not interpreted as erosional removal of the tephra.

\section{Slope angle}

The rate of erosion of tephra is assumed to be proportional to the sine of the slope angle (Young 1972). Measurements on Kodiak Island, in the Western Finisterre Ranges, and in Mt. Rainier National Park provide information on this relationship for thin tephra. The Kodiak Island measurements span an length of about $50 \mathrm{~km}$ on the north east of the island, the western Finisterres measurements were made in an area of a few hectares, while the Ohanopecosh data were collected from a single exposure at intervals of about $50 \mathrm{~mm}$. A general thinning of the tephra at all three locations with increasing slope angle is apparent but in no case is the relationship strong, with $\mathrm{r}^{2}$ ranging from 0.17 to 0.29 (Fig. 6). Slope angle - thickness relationships are marginally stronger for the St Helens W and Kodiak tephra than they are for the Western Finisterres (Tibito) tephra.

On Kodiak Island thinning on steeper slopes seems generally to have been accomplished by the removal of Layer 3 and the upper part of Layer 2 but detailed measurements are available at only a few sites. The field data indicate an essentially undisturbed thickness of Novarupta tephra of $150-210 \mathrm{~mm}$ on slopes of less than $15^{\circ}$. If we accept that the chosen sites are representative, then Fig. 6 indicates remarkably limited erosion of the tephra from slopes of less than c. $30^{\circ}$. Even some slopes of $35^{\circ}$ have retained $150 \mathrm{~mm}$ tephra cover; i.e., considerably more than half the original cover.

In the Western Finisterres, mean Tibito tephra thickness changes little with slope angle; that is, there is only limited thinning of tephra over a slope angle range of $40^{\circ}$. (Table 3, Fig. 6). Only the alluvial fan and landslide sites (Sites 10 and 13 in Table 3) show significant deposition and reworking of tephra, mean thickness having increased from c. $50 \mathrm{~mm}$ (judged from slope crest sites) to 80-110 mm. However, when the standard deviation of thickness values recorded at each site is considered (Table 3) most depositional sites (valley floors and alluvial fan) have a more varied tephra cover than do the erosional sites (slope crests and planar hillslopes). As depositional areas have numerous sites with tephra thickness $<50 \mathrm{~mm}$ these sites have clearly also suffered either non-deposition or significant erosion of the tephra. If we consider only the erosional hillslopes so that the data are comparable with that from Kodiak Island the sample is small, but it does not suggest marked thinning of tephra with increasing slope steepness.

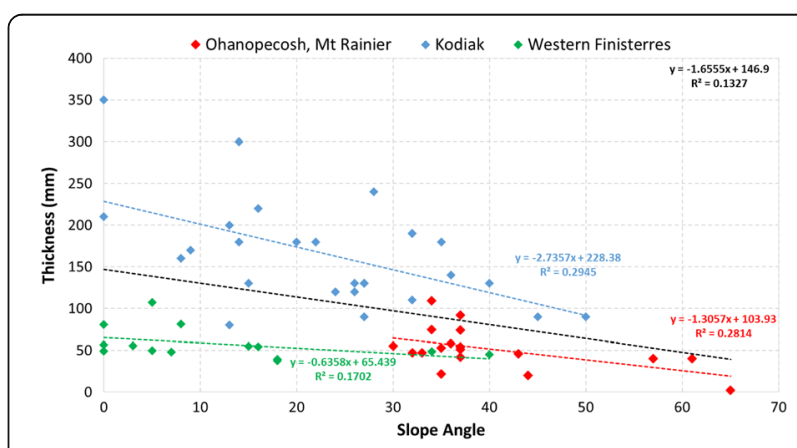

Fig. 6 Slope angles (degrees) versus tephra thickness measured normal to the slope at exposures of St Helens W at Ohanopecosh on Mt. Rainier, Novarupta tephra on Kodiak Island, and Tibito Tephra in the Western Finisterres. The Kodiak Island sites are spread out across about $50 \mathrm{~km}$ (see Fig. 3). The Western Finisterre data shows the mean thicknesses recorded at each of the 14 sites (in an area of a few hectares) listed in Table 3. The Ohanopecosh (Mt Rainier) measurements are in a small area with sites only $50 \mathrm{~mm}$ or so apart recorded against the local slope angle. At no site is the relationship between tephra thickness and slope angle strong 
Table 3 Sample site characteristics and Tibito Tephra thicknesses in the Western Finisterre Ranges, Papua New Guinea. N = no of samples at each site

\begin{tabular}{|c|c|c|c|c|c|c|}
\hline SITE No. & Geomorphic environment & Vegetation group & Slope angle (degrees) & Mean Tibito thickness (mm) & Standard deviation ( $\mathrm{mm}$ ) & $N$ \\
\hline 1 & Planar hillslope & 1 & $\sim 18$ & 39.3 & 40.7 & 7 \\
\hline 2 & 2nd order valley floor & 2 & 5 & 49.6 & 26.2 & 13 \\
\hline 3 & 2nd order valley floor & 2 & 15 & 55.0 & 30.3 & 12 \\
\hline 4 & Crest & 1 & 0 & 49.2 & 13.1 & 12 \\
\hline 5 & Planar hillslope & 2 & 7 & 48.2 & 18.3 & 11 \\
\hline 6 & Valley floor & 1 & 16 & 54.2 & 23.1 & 12 \\
\hline 7 & Crest & 1 & 3 & 55.5 & 28.1 & 11 \\
\hline 8 & Hillslope spur & 1 & 34 & 48.8 & 42.6 & 8 \\
\hline 9 & Short sideslope & 1 & 40 & 45.0 & 29.5 & 10 \\
\hline 10 & Alluvial fan & 2 & 8 & 81.4 & 48.0 & 11 \\
\hline 11 & Planar hillslope & 1 & 18 & 37.8 & 15.6 & 9 \\
\hline 12 & Valley basin floor & 3 & 0 & 80.5 & 43.7 & 10 \\
\hline 13 & Landslide & 2 & 5 & 107.5 & 102.5 & 2 \\
\hline 14 & Lake margin & 3 & 0 & 56.7 & 15.3 & 3 \\
\hline
\end{tabular}

On a general slope of $20-25^{\circ}$ under mature forest of Red cedar, Douglas fir and Western hemlock at Ohanopecosh (location on Fig. 2) on the southern slope of Mt. Rainier, tephra thickness measurements were made at $50 \mathrm{~mm}$ intervals along a short exposure and recorded against the local slope angle. Even within a short distance the forest floor has substantial microrelief, presumably as it had at the time of tephra emplacement. In such an area the tephra fall does not provide a continuous mantle of even thickness as the fall is intercepted by tree branches and reworked by stem flow and rain splash before arriving at the ground surface. Further reworking can occur after this initial emplacement so that it is sometimes possible to recognise an in situ thickness as well as a total thickness (in situ thickness + reworked thickness). There is a general thinning of tephra on steeper slopes but again the relationship is not particularly strong (Fig. 6).

\section{Geomorphic environments}

At the Western Finisterres site it is possible to divide the 14 sample sites into three general geomorphic environments - crests, erosional slopes and valley floors. The cumulative thickness of Tibito Tephra recorded in each of the geomorphic environments confirms that mean thicknesses on erosional slopes are thinner than those on valley floor (depositional) sites (Fig. 7). This also shows that Tibito Tephra was absent from $20 \%$ of the erosional sites sampled. The full range of thicknesses recorded occurs on both erosional slopes and depositional valley floors (0 to $180-190 \mathrm{~mm}$ ) while crest environments show a more limited range (0 to $110 \mathrm{~mm})$.

\section{Vegetation}

Three distinct vegetation assemblages are recognised at the Western Finisterres study area based on sums of squares agglomerative (SSA) classification of the 14 vegetation sites samples (Table 4). All sites were located above the altitudinal tree-line at 3500-3600 m above sea level in alpine shrubland/grassland. Group 1 (sites 1, 4, $6,7,8,9$, and 11) represents a low, woody shrubland typical of the well-drained upper slopes and ridges. Groups 2 (sites 2, 3, 5, 10, and 13) and 3 (sites 12 and 14) are dominated by herbaceous species occupying wetter valley floor locations. Sites 12 and 14, in particular, are found close to a small tarn on waterlogged ground. The SSA classification also shows that vegetation Groups 1 and 2 are more closely related to one another than they are to Group 3.

The small number of vegetation sample sites does not allow for detailed comparison with a classification of the landscape into geomorphic environments. However, a correlation between vegetation communities and geomorphology is apparent. All sites in Group 1 were identified as well-drained and relatively dry, while all sites in Groups 2 and 3 are wet, and mostly poorly-drained. A strong relationship also exists (not independently from that described above) between vegetation group and erosional vs depositional landscape units (Group $1=$ erosional, planar hillslopes plus ridge crests; Groups 2 and 3 = depositional, alluvial fans, valley bottoms, $\mathrm{X}^{2}=8.04$, $p<0.01)$.

A wide range of Tibito Tephra thicknesses are associated with all three vegetation types though shrublands on well drained slopes (Group 1) has the most cores where tephra is absent and where median tephra 

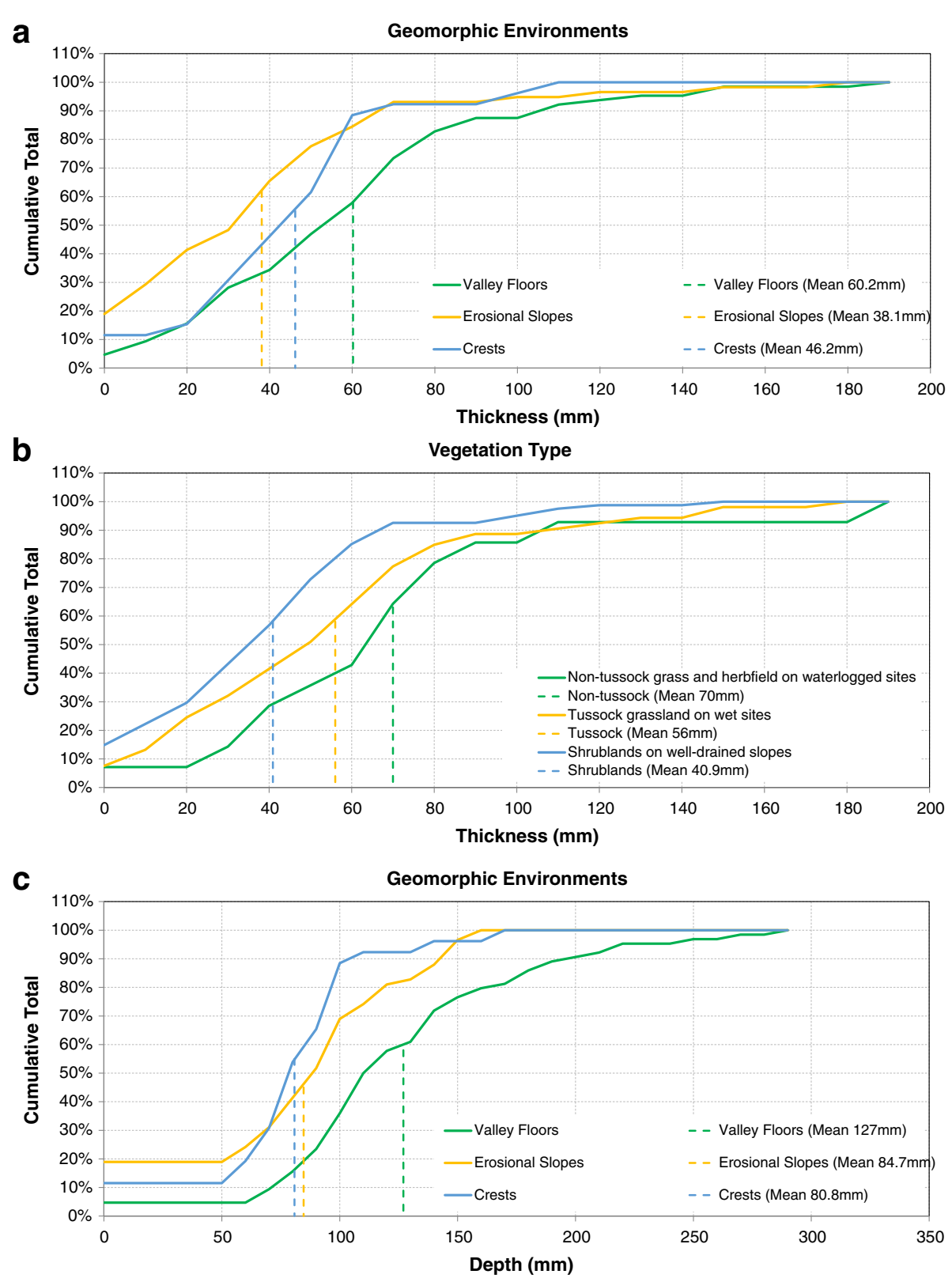

Fig. 7 a Cumulative totals of Tibito Tephra thickness for valley floor, erosional slopes, and slope crest geomorphic environments in the Western Finisterres. Median thicknesses for crest environments lie between those for erosional and depositional environments. Note that Tibito Tephra was absent from $20 \%$ of the erosional slope sample cores, $12 \%$ of the crest sample cores, and $5 \%$ of the valley floor cores; b Cumulative thicknesses and mean thicknesses of Tibito Tephra in non-tussock grassland and herbfield (waterlogged) sites, tussock grassland (wet) sites, and shrubland (well-drained) slopes; c Depth of burial of the surface of Tibito Tephra recorded in alpine grasslands at elevations around $3600 \mathrm{~m}$ above sea level. Cumulative rates of burial for valley floor, erosional slope, and slope crest geomorphic environments are shown. The survey was conducted about 330 years after deposition of Tibito Tephra

thickness is less than on the wetter tussock and nontussock sites (Fig. 8).

Pollen analysis was carried out on samples taken immediately above and below Tibito Tephra on two short soil cores for key pollen types indicating the presence of either grassland/shrubland (Poaceae and Cyperaceae pollen), or forest (Rapanea and Dacrycarpus pollen).
Results conform to the findings of Corlett (1984a, 1984b) for Mt. Wilhelm $\left(5.77^{\circ} \mathrm{S}, 145.03^{\circ} \mathrm{E}\right.$; see location on Fig. 1) in the nearby Bismarck Ranges, PNG. He describes a major change from forest to grassland/shrubland for 28 sites on Mt. Wilhelm immediately following emplacement of Tibito Tephra. This change is not related in any way to the ash fall; rather, it appears to 
Table 4 Dominant plant species associated with each of the three alpine communities identified by SSA classification at the Western Finisterres, Papua New Guinea. Not all plants could be identified to species level since only a small proportion of the flora was in flower at the time of the study. All species were identified by staff of the Lae Herbarium, Papua Guinea

\begin{tabular}{|c|c|c|}
\hline Group & Community type & $\begin{array}{l}\text { Dominant } \\
\text { species }\end{array}$ \\
\hline \multirow{7}{*}{$\begin{array}{l}1 \text { Site Nos: } 1,4,6 \text {, } \\
7,8,9,11\end{array}$} & \multirow{7}{*}{$\begin{array}{l}\text { Shrublands on well-drained slopes } \\
\text { ( }>7 \text { degrees) }\end{array}$} & Selliguea sp. \\
\hline & & $\begin{array}{l}\text { Gaultheria } \\
\text { mundula }\end{array}$ \\
\hline & & $\begin{array}{l}\text { Styphelia } \\
\text { suaveolens }\end{array}$ \\
\hline & & $\begin{array}{l}\text { Coprosma } \\
\text { divergens }\end{array}$ \\
\hline & & $\begin{array}{l}\text { Gleichenia } \\
\text { bolanica }\end{array}$ \\
\hline & & $\begin{array}{l}\text { Festuca sp. } \\
\text { (papuana?) }\end{array}$ \\
\hline & & Myosotis linearis \\
\hline \multirow[t]{5}{*}{$\begin{array}{l}2 \text { Site Nos: 2, 3, 5, } \\
10,13\end{array}$} & \multirow[t]{5}{*}{ Tussock grassland on wet sites } & $\begin{array}{l}\text { Deschampsia } \\
\text { klossii }\end{array}$ \\
\hline & & $\begin{array}{l}\text { Drapetes } \\
\text { ericoides }\end{array}$ \\
\hline & & Astelia papuana \\
\hline & & Potentilla sp. \\
\hline & & $\begin{array}{l}\text { Rhododendron } \\
\text { womersleyi }\end{array}$ \\
\hline \multirow[t]{6}{*}{3 Site Nos: 12,14} & \multirow{6}{*}{$\begin{array}{l}\text { Non-tussock grass and herbfield } \\
\text { on waterlogged sites }\end{array}$} & Astelia papuana \\
\hline & & $\begin{array}{l}\text { Monostachya } \\
\text { oreoboloides }\end{array}$ \\
\hline & & Trachymene sp. \\
\hline & & $\begin{array}{l}\text { Potentilla sp. } \\
\text { (fousteriana?) }\end{array}$ \\
\hline & & Carpha alpina \\
\hline & & Ranunculus sp. \\
\hline
\end{tabular}

represent a chance correlation with the increasing population of people at high altitude (and their burning of the forest) following the introduction of sweet potato (Ipomoea batatas) to the New Guinea highlands. ${ }^{2}$ Introduction of the sweet potato is thought to have allowed the extension of agricultural activities altitudinally by about $600 \mathrm{~m}$ (Corlett 1984a).

That the tephra has been preserved under grassland in the sites studied agrees with the observational information available for PNG which suggests very limited preservation of tephra under forest.

There are several possible reasons for the poor preservation of tephra layers in forested areas of New Guinea (and other rainforest regions). Firstly, the variable thickness of canopy cover, combined with ground layer obstacles such as fallen trees, rotting stems, and the location of living stems, precludes the even distribution of ash on

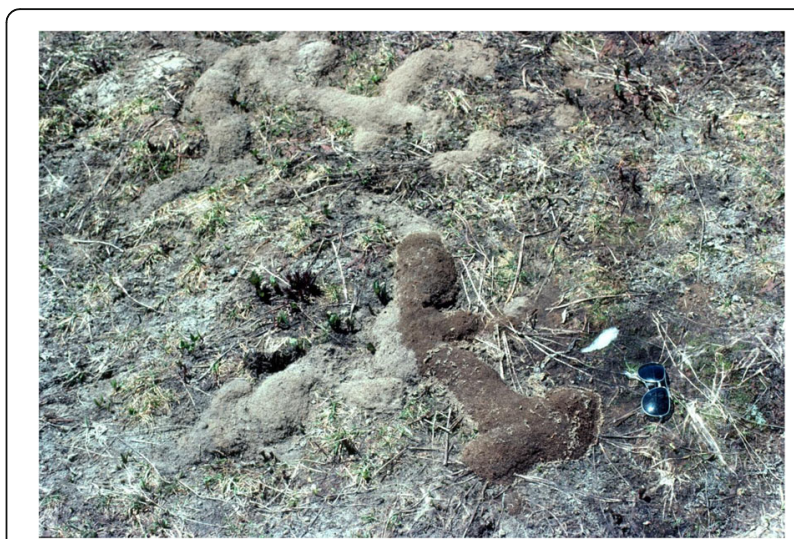

Fig. 8 Gopher trails in an alpine meadow, Chinook Pass, Mt. Rainier National Park

the forest floor. ${ }^{3}$ Secondly, various authors have calculated the mean turnover rate of trees within rainforest to range between 40 and 180 years (Hartshorn 1978, 1980). This rapid rate of cycling implies regular disturbance of the forest soil by treefall and mixing of surface and subsurface soil horizons including thin tephra. Thirdly, soil fauna may play an active part in mixing of the soil.

\section{Faunal activity}

Experimental plot studies at Mt. Hagen (PNG) illustrate that a relatively even, compacted tephra layer can be expected to develop within a few weeks of ash fall in short $(<200 \mathrm{~mm})$ grassland. In grasslands of the lowland tropics, the mixing activities of termites likely preclude survival of thin tephra. Although 350-year old Tibito Tephra has been 'mapped' across tens of thousands of square $\mathrm{km}$ on the PNG mainland (Blong 1982) it has been recorded at very few lowland sites away from the coast other than in sites with special preservation characteristics such as in lakes and swamps.

However, termites are absent from alpine grasslands and there is little mixing activity by the "depauperate" soil fauna. The pattern of grass growth and mortality is also less likely to disturb the tephra. Death of plant parts (i.e. tillers above ground, and roots below ground) is followed by decomposition in situ. Thus, organic matter is added to the soil surface, and some is incorporated into the soil profile as roots decompose. The tephra layer receives some organic inputs through root decomposition, but is not greatly affected.

Survival of the 500-year old ${ }^{4}$ Mount St Helens Wn tephra as a recognisable layer under forest at high altitude near Mt. Rainier, USA, is more difficult to explain. The rate of turnover at these sites may be much lower (perhaps $>300$ years) due to the greater longevity (and slower growth rates) of trees typical of montane forests in the middle latitudes of the northern hemisphere. Also, 
the lower temperatures, especially in winter at Mt. Rainier, compared with tropical montane forest areas may reduce soil faunal activity. These factors could allow longer survival of identifiable tephra.

Mount Rainier and the highlands of PNG provide an interesting contrast. In highland PNG Tibito Tephra is preserved under grassland but not under forest, whereas the opposite appears to be the case with Mount St Helens Wn tephra on the eastern slopes of Mount Rainier; slower biological turnover may at least partly explain the presence of Wn tephra under forest at Mt. Rainier while macrofauna appear responsible for destruction of the tephra layer in alpine meadow areas of Mt. Rainier National Park.

In the Sunrise - Sunrise Point and Sourdough Trail areas of the park on south-facing slopes at elevations of 1900-2000 m St Helens W tephra should be 20+ mm thick (Fig. 2). In these areas, more than $5 \mathrm{~km}$ of exposure was examined. Mount St Helens W tephra is absent in alpine meadow/herbfield areas even on ridge crests and gentle slopes. Small white pumice grains commonly occur just below the surface and some areas have a "saltand-pepper" appearance as described by Mullineaux (1974), p37-38. The single alpine meadow exposure of W tephra in the Sunrise area, found near the Sunrise campground, was $350 \mathrm{~mm}$ long with an average thickness of $20 \mathrm{~mm}$.

In the Chinook Pass - Tipsoo Lake area at 1600$1800 \mathrm{~m}$ the tephra is again absent from the alpine meadows though Mullineaux's map (Fig. 2) indicates that W tephra should be $30-40 \mathrm{~mm}$ thick. Except for two small lenses about $100 \mathrm{~mm}$ long where W tephra was $50-80 \mathrm{~mm}$ thick no exposures could be found. Nonetheless, loose pumiceous sand, believed to be W tephra was scattered everywhere.

However, in both the Sunrise and the Chinook Pass areas Mount St Helens W tephra is extensive under patches of white bark pine (Pinus albicaulis) and yellow cedar (Chamaecyparis nootkatensis) forest. The stunted trees of these small forest patches are probably at least several hundred years old. These observations perhaps suggest that the present day distribution of $\mathrm{W}$ is influenced by vegetation type, but it is also possible that $\mathrm{W}$ fell onto snow or that reworking and removal of $\mathrm{W}$ under meadow conditions could result from the activity of the northern pocket gopher (Thomomys talpoides). The latter seems more plausible as tephra fall onto snow would still result in at least recognisable lenses of tephra after snow melt.

Gopher activity in meadows around Sunrise and Chinook Pass is everywhere in evidence. The pocket gopher remains active in winter, forming tunnels through the snow just above the ground. Soil excavated from tunnels $40-200 \mathrm{~mm}$ below the surface is placed in the snow tunnels. Spring melting leaves ridges of soil across the meadows (Fig. 8). The northern pocket gopher avoids forests, preferring a diet rich in forbs, and living in deep light soils. Wintertime territories are frequently flooded, promoting a seasonal change in territory and distributing the impact of their burrowing activities even more widely (Schamberger 1971; Thorn 1978).

The available evidence suggests that pocket gophers, despite individual lifespans of only 2-3 years (Johnson and Horwath Burnham 2012), have almost completely reworked $20-40 \mathrm{~mm}$ thick layers of W tephra in alpine meadow sites in 500 years or less. This is in accord with the observation of Andersen and MacMahon (1985) that gopher activities had covered up to $2 \%$ of the ground surface with pre-Mount St Helens 1980 soil in the first 4 months after the 1980 eruption and with those of Kyoo et al. (2005) where soil turnover in the upper $50 \mathrm{~cm}$ by gophers occurs in only 40-100 years on California hillslopes. Despite this apparently rapid turnover of W tephra in alpine meadows, Layer $\mathrm{W}$ is well preserved in forest areas.

On the Mt. Hagen experimental plots faunal activity resulted in marked mixing of the tephra and even its destruction on parts of plots in a little more than 2 years. Observations made at 1 month and 8 months (Table 2) indicate an increase in the variability of tephra thickness. On some plots the tephra developed a crumb topsoillike structure but with little mixing of organic matter. On other plots the tephra formed clods with downward mixing of as much as $50 \mathrm{~mm}$. Earthworm activity was evident. After 8 months the tephra layers were surprisingly well preserved even when "sown" as a $10 \mathrm{~mm}$ layer onto grasses $300 \mathrm{~mm}$ high or even onto a simulated garden surface (Plot 7).

However, after 25 months preservation of the tephra was much less complete. On Plot 6 where tephra had been only $10 \mathrm{~mm}$ thick, the tephra had virtually disappeared with only a few small balls $3-4 \mathrm{~mm}$ in diameter readily visible. Even portions of $50 \mathrm{~mm}$ thick layers had vanished on Plot 2. On Plot 7 a diffuse layer of tephra could be recognised in the top 60-70 $\mathrm{mm}$ but the tephra was buried by $10-20 \mathrm{~mm}$ of topsoil. No doubt mixing was produced by a range of soil fauna but earthworm activity was most evident.

Following Wood and Johnson (1978) two broad soilforming processes can be recognised - horizonation, represented here by the deposition of a layer of volcanic ash, and homogenization, pedoturbation or soil mixing produced by subsequent burial of the tephra layer. In areas without termites, earthworms are the most widely recognised faunal agent for soil mixing with measured rates in the range 360-9000 kg/ha/y (Wood and Johnson 1978). While the experimental plots in Mt. Hagen at $1500 \mathrm{~m}$ elevation showed rates of burial of tephra of up 
to $5 \mathrm{~mm} / \mathrm{y}$ the longer-term rates measured in the Western Finisterres at $3600 \mathrm{~m}$ elevation averaged only 0.2$0.3 \mathrm{~mm} / \mathrm{y}$ with valley floors and tussock grasslands on wet sites showing the highest rates (Fig. 7c).

\section{Variability in tephra thickness}

In order to determine potential uncertainties surrounding the accuracy and precision of our Western Finisterres sampled data we have followed Engwell et al. (2013) in estimating observational uncertainty, or simply the standard deviation normalised to the average thickness for each sample site. There is significantly more variation within the uncertainty associated with the samples taken on erosional slopes when compared to crests and valley floors (Fig. 9a). There is substantially less spread between the samples taken at the crests and valley floors. The Vegetation type data (Fig. 9b) show for Shrublands on well-drained slopes and Tussock grasslands on wet sites that uncertainty between the observation data is independent of each environment or rather one environment does not provide stability of precision of sampled data over the other. This conclusion cannot be applied to the Non-tussock grass and herbfield sites as there are only two in this category.

Observations made in the four study areas in Papua New Guinea, Washington State and Alaska indicate that the thickness of thin tephra is quite variable over small areas and in time periods spanning a few months to 500 years. Our observations in the Western Finisterre Ranges are of particular interest as they raise questions about the representativeness of isolated measurements of tephra thickness, the number of measurements necessary to determine mean thickness adequately, and attendant inaccuracies in isopach maps of tephra distribution and estimates of ashfall volume.

Measured thicknesses ranged from 1 to $19 \mathrm{~cm}$ but Tibito Tephra was missing from 17 cores $(11.8 \%$ of cores). Mean thickness for all 148 cores was $49.1 \pm 36.5 \mathrm{~mm}$, but if only those cores where Tibito Tephra was identified are sampled the mean becomes $55.4 \pm 34 \mathrm{~mm}$.

Mean tephra thickness for the 1912 Novarupta tephra sampled on Kodiak Island is about $160 \mathrm{~mm}$ with

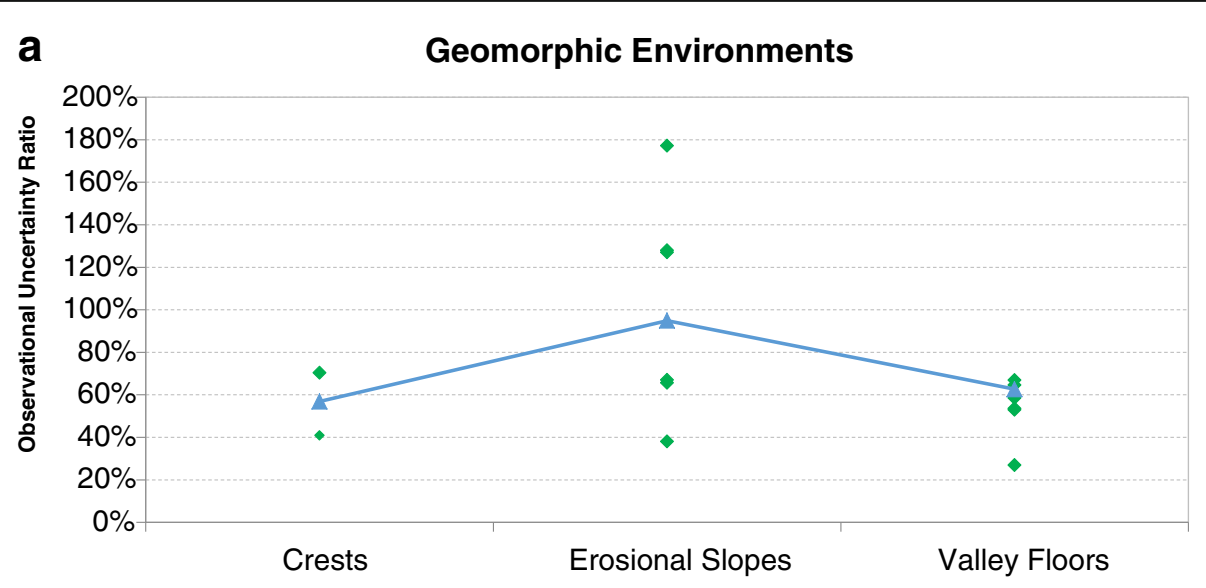

b Vegetation Type

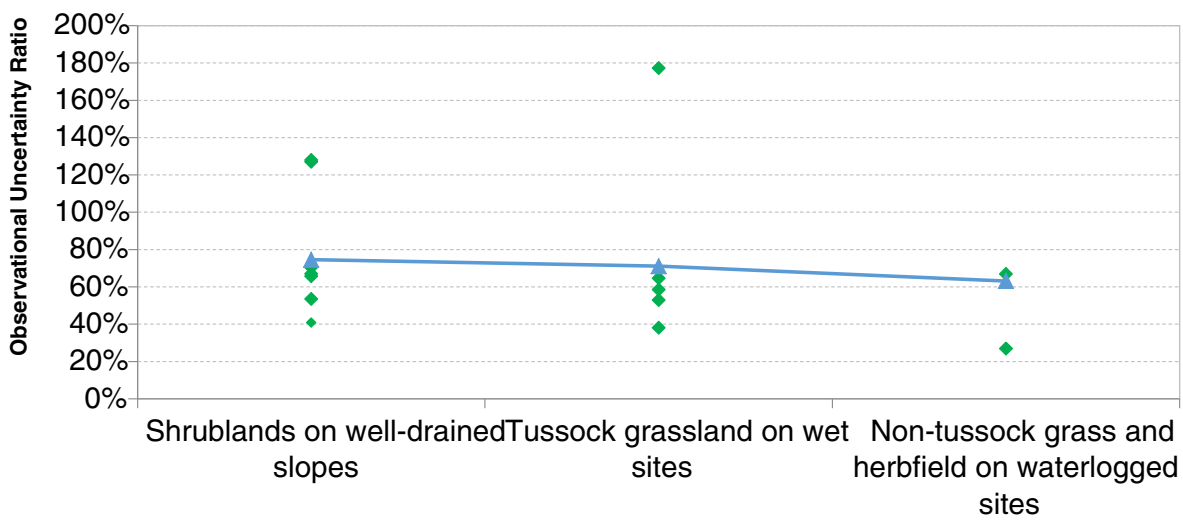

Fig. 9 Observational Uncertainty estimated, following Engwell et al. (2013), for western Finisterre sites. a Geomorphic environments; b Vegetation types 
Standard Deviation (SD) $=63.4 \mathrm{~mm}$ (Fig. 10). As for Tibito Tephra, Novarupta tephra thickness also varies markedly over small areas. Figure 10 also shows the variability in thicknesses recorded at just one of the Kodiak sample sites - Site X 7.

Site X 7, near Kalsin Bay (Fig. 3), has a north eastern aspect on an undulating slope of 6-10 degrees 20-30 m above sea level and underlain by about $1 \mathrm{~m}$ of brown soil on till. The site was covered with grasses, fireweed, salmonberry, and mosses with part of the site just $20 \mathrm{~m}$ from a spruce forest. Tephra cover appeared to be continuous with 24 measurements made at about $5 \mathrm{~m}$ intervals along the road cutting. Figure 10 shows the variability in tephra thickness in this essentially homogeneous site. All three layers of Novarupta tephra could be recognised at only 6 of the 24 sites, with Layer 3 present at 7 of the 24 sites. Mixing and diffusion were most common at the top of the tephra and rare at the sharp and regular base (cf. Fig. 4). The range in thickness appeared to result mainly from the surface microrelief of the site before tephra deposition. Interestingly, the mean and SD of the thickness at this one site with all measurements within $120 \mathrm{~m}$ or so of one another are essentially the same as the mean and SD for all 26 sites measured on Kodiak Island which are spread out across more than $50 \mathrm{~km}$ of the north eastern coast (for 26 sites: Mean $=164 \mathrm{~mm} ; \mathrm{SD}=63.4 \mathrm{~mm}$; for Site X7: Mean $=160 \mathrm{~mm}$; SD = $61.8 \mathrm{~mm}$ ).

The high variability in tephra thickness shown in the Western Finisterres and the Kodiak sites has implications for how many samples are necessary to confidently determine mean tephra thickness at sites with thin tephra (i.e. less than $200 \mathrm{~mm}$ ). Table 5 summarises the number of records, mean thickness and the standard deviation of the thickness for the Western Finisterres, Ohanopecosh and Kodiak sites. The 'Confidence' column shows the confidence we have that the mean thickness is correct to within $\pm 10 \mathrm{~mm}$ and the last column indicates the number of thickness measurements required at each site to estimate the mean thickness with $95 \%$ confidence.

If the sample statistics shown in Table 5 are representative of thin tephra variability within small sample areas, there are few studies where we can be confident that we have adequately assessed mean tephra thickness, and we need many more measurements to be reasonably certain that our conclusions are soundly based.

\section{Conclusions and implications}

Based on the Mt. Hagen tephra deposition experiment, compaction occurs rapidly after deposition, primarily, we suspect, as a result of raindrop impact; records of tephra thickness (and of bulk density) may be quite dependent on how long after deposition measurements were made. While much of the evidence is little more than anecdotal, both thickness and bulk density measurements of "freshly fallen tephra" reported in the literature need to be interpreted with care. Careful analyses of freshly fallen tephra across a range of thicknesses, grain sizes, and environmental conditions are required.

While the statement that individual sand and silt-sized tephra grains may be retained on leaves and take weeks or longer to reach the ground surface is of no surprise, the observation that some 1912 Novarupta tephra was still perched on some of the large horizontal branches of spruce trees 66 years after the eruption is more startling. Deposition of these moss-covered lenses of tephra in a stratigraphic soil sequence may not take place until tree fall occurs, perhaps hundreds of years after the tephra fall.

Erosional reworking of thin tephra at the sites examined is not rapid even on steeper slopes. At the high altitude Western Finisterres and the high latitude Kodiak Island sites thin tephra remain well preserved for decades to centuries despite the relatively high rainfalls in both environments. Nonetheless, in the Western

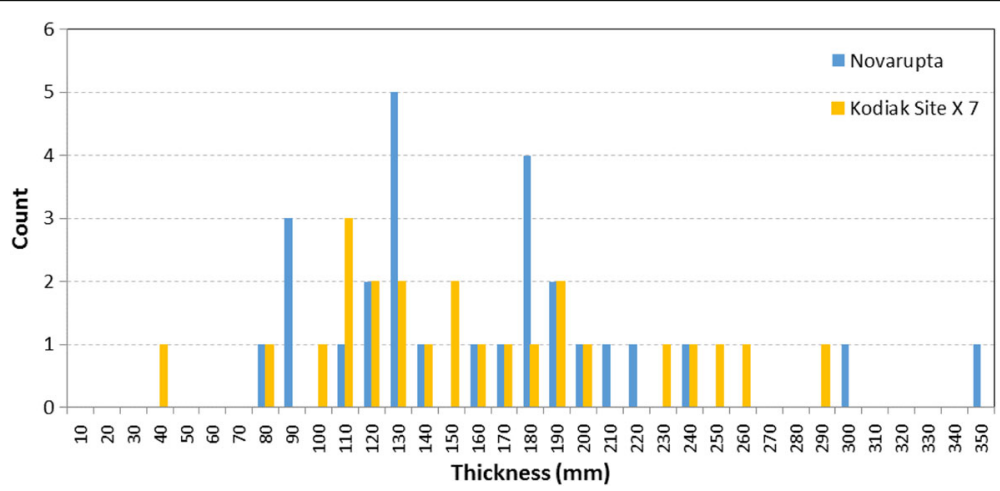

Fig. 10 Variability of Novarupta (1912) tephra thickness at 26 sample sites on the north eastern portion of Kodiak Island and tephra thicknesses at Kodiak Site X 7 (location on Fig. 3), an exposure spanning just $120 \mathrm{~m}$ in length. Kodiak Island (26 sites): Mean = $164 \mathrm{~mm}$; SD = $63.4 \mathrm{~mm}$, Kodiak Site $X 7$ : Mean $=160 \mathrm{~mm} ; \mathrm{SD}=61.8 \mathrm{~mm}$ 
Table 5 Sample sizes, mean thicknesses and standard deviations of tephra thickness at each of the sample sites. Confidence limits for the sample size assuming a $10 \mathrm{~mm}$ error in mean thickness is acceptable and the number of samples required to estimate the mean thickness with $95 \%$ confidence

\begin{tabular}{|c|c|c|c|c|c|}
\hline Location & $n$ & $\bar{x}$ & $\delta$ & Confidence; 10 mm Error & n; 95\% Confidence Interval \\
\hline W Finisterres, PNG & 148 & 49.1 & 36.5 & $99.9 \%$ & 52 \\
\hline Crests & 26 & 46.2 & 26.2 & $94.8 \%$ & 27 \\
\hline Erosional slopes & 58 & 38.1 & 36.2 & $96.5 \%$ & 51 \\
\hline Depositional sites & 64 & 60.2 & 37.7 & $96.6 \%$ & 55 \\
\hline Non tussock; waterlogged & 14 & 70.0 & 44.2 & $60.5 \%$ & 76 \\
\hline Tussock; wet sites & 53 & 56.0 & 39.8 & $93.3 \%$ & 61 \\
\hline Shrublands; well-drained & 81 & 40.9 & 30.5 & $99.7 \%$ & 36 \\
\hline Ohanopecosh, WA & 19 & 51.6 & 24.5 & $92.5 \%$ & 24 \\
\hline Kodiak, AK & 26 & 164.0 & 63.4 & $57.6 \%$ & 155 \\
\hline Kodiak Site X7 & 24 & 160.4 & 61.8 & $57.1 \%$ & 147 \\
\hline
\end{tabular}

Finisterres, mean and median thicknesses on slope crests lie between those for erosional slopes and depositional valley floors, and the observational uncertainty estimated from the erosional sites is substantially larger than for slope crest and valley floor sites.

On erosional slopes in the Western Finisterres 20\% of soil cores recorded no tephra, compared with $12 \%$ on slope crests and $5 \%$ on valley floors, emphasising that a reasonable number of sites or cores need to be examined to confirm the presence/absence of thin tephra.

Biological activity plays a major role in tephra preservation. In PNG the 350-year old Tibito Tephra is not present under forest but is well-preserved in alpine grasslands. On Mt. Rainier 500-year old tephra is readily preserved under forest where biological turnover is assumed less rapid than in highlands PNG but absent as an identifiable layer under grasslands where gophers thoroughly mix soils, evidently within a few decades of deposition.

The depth of burial of Tibito Tephra by subsequent biological activity is greatest on valley floors, least on slope crests, and intermediate on 'erosional' slopes. The depth of burial of the tephra is least on shrublands on well-drained sites waterlogged non-tussock grass and herbfield sites, and greater on wet tussock grassland sites.

Despite the weak relationship between slope steepness and tephra thickness, variability in thickness is quite high. On Kodiak Island variability across even a few metres is similar to that observed across the whole north eastern end of the island.

The marked variability in thickness for thin tephra suggests that large (even impractically large) samples sizes are necessary to adequately determine mean tephra thickness with reasonable confidence.

Our observations emphasise the importance of rapid initial compaction, vegetative substrate and faunal activity as factors influencing survival and preservation of thin tephra. These conclusions stand in contrast to the emphasis on rapid erosional removal reported for thicker tephra. These observations of thin tephra preservation here are of significance in interpreting tephrostratigraphic sequences, the recording of mean tephra thickness, the construction of isopach maps, and the determination of ashfall volumes and eruption magnitudes. They may also be relevant to the interpretation of archaeological sites and lacustrine sequences.

\section{Endnotes}

${ }^{1}$ Fierstein and Hildreth (1992) recognise eight Novarupta (1912) tephra and six colour "zones" of tephra on Kodiak Island. Their rhyolitic plinian layer A and compositionally heterogeneous $\mathrm{B}$ appear to correspond to Reiger and Wunderlich's (1956) Layer 1, plinian dacite $\mathrm{C}+\mathrm{D}$ and fine ash $\mathrm{E}$ with layer 2, and plinian dacite $\mathrm{F}+\mathrm{G}$ and fine ash $\mathrm{H}$ with Layer 3, recognising that subunit distinctions fade with distance from the source.

${ }^{2}$ The timing of the introduction of the sweet potato into Papua New Guinea is a matter of debate. See, for example, Ballard et al. (2005)

${ }^{3}$ Griggs (1922, p28 and 38) includes photographs of old forest spruce with moss-covered trunk and branches loaded with ash near Kodiak and comments "moss balls held quantities of the falling ash, which have since been consolidated and bound in place by new growth". In 1978 David Gringrich of Kodiak Island pointed out to the first author that large horizontal branches on some old spruce trees still had 1912 Novarupta tephra on upper surfaces with moss growing on them. Sixty six years after the eruption, some Novarupta tephra had still not reached the ground!

${ }^{4} 500$ years old in 1978 at the time of the investigation reported here. 


\section{Acknowledgements}

Fieldwork in the Papua New Guinea highlands was supported by Macquarie University, Australian National University, the Australian Research Council and the Papua New Guinea Biological Foundation. Fieldwork on Mt. Rainier was supported by the US National Park Service and the Quaternary Research Unit of the University of Washington. RJB is particularly grateful to David Gringrich of Chiniak Point, Kodiak Island, for his friendship, assistance and accommodation. We also thank staff of the Lae Herbarium for species identification and to Dr. R Corlett for pollen analysis of cores from the Western Finisterres. Our special thanks to Dr. Keping Chen of www.BigDataEarth.com for developing Figs. 1, 2 and 3.

Our sincere thanks to the referees who made numerous comments which have enabled us to improve the manuscript significantly.

An early version of this manuscript has been available in the Murdoch University Library Research Repository (http://researchrepository.murdoch.edu.au/ 5785/) for some years. The current publication extends and updates that manuscript.

\section{Authors' contributions}

Fieldwork and data analysis for the Western Finisterres, PNG study was undertaken by NE and RB. RB developed and maintained the experimental plots in Mount Hagen, PNG and performed the field measurements on Kodiak Island and around Mount Rainier. All statistical analysis was completed by PG. All authors read and approved the final manuscript.

\section{Competing interests}

The authors declare that they have no competing interests.

\section{Publisher's Note}

Springer Nature remains neutral with regard to jurisdictional claims in published maps and institutional affiliations.

\section{Author details}

'Risk Frontiers, Macquarie University, Sydney, NSW 2009, Australia. ${ }^{2}$ School of Veterinary and Life Sciences, Murdoch University, 90 South St, Murdoch, WA 6150, Australia. ${ }^{3}$ Ashbury, NSW 2193, Australia.

Received: 2 July 2016 Accepted: 18 May 2017

Published online: 05 June 2017

\section{References}

Andersen DC, MacMahon JA. Plant succession following the Mount St Helens volcanic eruption: facilitation by a burrowing rodent, Thomomys talpoides. Am Midl Nat. 1985;114(1):62-9.

Anderson T, Flett JS. Report on the eruptions of the Soufrière in St Vincent, and on a visit to Montagne Pelée in Martinique. Phil Trans R Soc London. 1903; A200:353-553.

Aramaki S. The 1783 activity of Asama volcano, part 1. Jpn J Geol Geog. 1956;27:189-229.

Arnalds O. The Influence of Volcanic Tephra (Ash) on Ecosystems. In: Advances in Agronomy. Elsevier; 2013. 121: 331-380.

Ballard C, Brown P, Bourke R M, and Harwood T (eds). The sweet potato in Oceania: a reappraisal, Ethnology Monograph 19, University of Pittsburgh, Oceania Monograph 56. Sydney: University of Sydney; 2005.

Blong RJ. The time of darkness - local legends and volcanic reality in Papua New Guinea. Seattle: University of Washington Press; 1982.

Cilento R. The volcanic eruption in Blanche Bay, territory of New Guinea, May 1937. Hist Soc Qld J. 1937;3:37-49.

Collins BD, Dunne T. Erosion of tephra from the 1980 eruption of Mount St Helens. Geol Soc Am Bull. 1986:97:896-905.

Collins BD, Dunne T, Lehre AK. Erosion of tephra-covered hillslopes north of Mount St Helens, Washington: may 1980-may 1981. Zeischrift für Geomorph Suppl Bd. 1983;46:103-21.

Corlett RT. Human impact on the sub-alpine vegetation of Mt Wilhelm, Papua New Guinea. J Ecol. 1984a; $72: 841-54$

Corlett RT. Palynological evidence for changing subsistence patterns around Mt Wilhelm, Papua New Guinea. Singapore J Trop Geog. 1984b;5:102-11.

Duncan AR, Vucetich CG. Volcanic activity on White Island, Bay of Plenty, 1966-69. Part 2- Tephra eruptions - stratigraphy and petrography. N Z J Geol Geophys. 1970;13:969-79.

Engwell SL, Sparks RSJ, Aspinall WP. Quantifying uncertainties in the measurement of tephra fall thickness. J Appl Volcanol. 2013;2:5. doi:10.1186/2191-5040-2-5.
Erskine H. Katmai's black-out. Ketchikan: Alaska Sportsman Magazine; 1940. 22:16-17. Erskine WF. Katmai. London: Abelard-Schuman; 1962.

Fierstein J, Hildreth W. The Plinian eruptions of 1912 at Novarupta, Katmai National Park, Alaska. Bull Volcanol. 1992:54:646-84.

Gorshkov GS. Gigantic eruption of volcano Bezymianny. Bull Volcanol. 1959;20:77-109.

Gorshkov GS, Dubik YM. Gigantic directed blast at Shiveluch volcano (Kamchatka). Bull Volc. 1970;34:261-88.

Griggs RF. The recovery of vegetation at Kodiak. Ohio J Sci. 1918;19(1):1-57.

Griggs RF. The Valley of Ten Thousand Smokes. Washington, D.C.: The National Geographic Society; 1922.

Hartshorn GS. Tree falls and tropical forest dynamics. In: Tomlinson PB, Zimmerman MH, editors. Tropical trees as living systems. London: CUP; 1978. Hartshorn GS. Neotropical forest dynamics. Biotropica. 1980;12(suppl):23-30.

Higashi S, Araya T, Onodera H. Studies on the debris-flow and erosion control works at Mt Usu. Usu eruption and its impact on environment. Sapporo: Hokkaido University; 1978. 87-99.

Hildreth W, Fierstein J. Katmai volcanic cluster and the great eruption of 1912. Geol Soc Am Bull. 2000;112(10):1594-620.

Hilton MR. Quantifying post depositional redistribution of the archaeological record produced by freeze-thaw and other mechanisms: an experimental approach. J Archaeol Method Theory. 2003;10(3):165-202.

HMSO. Further correspondence relating to the volcanic eruptions in St Vincent and Martinique, in 1902 and 1903. London: His Majesty's Stationery Office; 1903.

Huggins P F (1902) Report on the Soufrière Saint Vincent, B.W.I. (no publisher given).

Johnson D L, Horwath Burnham J L. Introduction: overview of concepts, definitions, and principles of soil mound studies. In: Horwath Burnham JL, Johnson DL (eds.) Mima Mounds: the case for polygenesis and bioturbation. Boulder: Geological Society of America Special Paper; 2012. 490: 1-19.

Kadomura H, Yamamoto H, Suzuki R, Suzuki K. Some aspects of erosional form and process on tephra-covered hillslopes produced by the 1977 eruption of Usu volcano, Hokkaido: August 1977-Early August 1978, Usu eruption and its impact on environment. Sapporo: Hokkaido University; 1978. p. 121-39.

Kyoo K, Amundson R, Heimsath AM, Dietrich WE. Process-based model linking pocket gopher (Thomomys bottae) activity to sediment transport and soil thickness. Geology. 2005;33(11):917-20.

Lowdermilk WC, Bailey RW. A look at Paricutin. Soil Conserv. 1946;1 1(12):280-8.

Lowe DJ. Tephrochronology and its application: a review. Quat Geochronol. 2011; 6(2):107-53.

Martin GC. The recent eruption of Katmai volcano in Alaska. Natl Geogr. 1913; 24(2):131-81.

Moore JG. Base surge in recent volcanic eruptions. Bull Volcanol. 1967;30:337-63.

Mullineaux DR. Pumice and other pyroclastic deposits in Mount Rainier National Park. U.S. Geol Surv Bull. 1974;1326:1-83.

Mullineaux DR, Hyde JR, Rubin M. Widespread late glacial and postglacial tephra deposits from Mt St Helens volcano, Washington. US Geol Surv J Res. 1975; 3(3):329-35.

Ollier DC, Brown MJF. Erosion of a young volcano in New Guinea. Zeitschrift für Geomorph. 1971;15:12-28.

Orloći L. Multivariate analysis in vegetation research. 2nd ed. The Hague: Dr W Junk; 1978. p. 451.

Payne RJ, Symeonakis E. The spatial extent of tephra deposition and environmental impacts from the 1912 Novarupta eruption. Bull Volcanol. 2012;74:2449-58.

Reiger S, Wunderlich RE. Soil survey and vegetation of northeastern Kodiak Island area, Alaska. US soil conservation service and US Bureau land management. Soil Surv Ser. 1956;17:1-46.

Schamberger ML. Mount Rainier's mammals. lowa: Anundsen Publ Co; 1971. p. 79.

Thorarinsson S, Sigvaldason GE. The Hekla eruption of 1970. Bull Volcanol. 1972; 36:269-88.

Thorn CE. A preliminary assessment of the geomorphic role of pocket gophers in the alpine zone of the Colorado front range. Geogr Ann. 1978;60A(3-4):181-7.

Waldron HH. Debris flow and erosion control problems caused by the ash eruptions of Irazú volcano, Costa Rica. US Geol Surv Bull. 1967;1241-1:1-37.

Wilcox RE. Some effects of recent volcanic ash falls with especial reference to Alaska. USGS Bull. 1959;1028-N:409-74.

Wood WR, Johnson DL. A survey of disturbance processes in archaeological site formation. Adv Archeol Method Theory. 1978;1:315-80.

Yamaguchi DK. New tree-ring dates for recent eruptions of Mt St Helens, Washington. Quat Res. 1983;10:246-50.

Young A. Slopes. London: Oliver and Boyd; 1972. 